Article

\title{
Social Media Goes Green-The Impact of Social Media on Green Cosmetics Purchase Motivation and Intention
}

\author{
Rebeka-Anna Pop * (D), Zsuzsa Săplăcan 10 and Mónika-Anetta Alt
}

Faculty of Economics and Business Administration, Babeș-Bolyai University, 400000 Cluj-Napoca, Romania; zsuzsa.pal@econ.ubbcluj.ro (Z.S.); monika.alt@econ.ubbcluj.ro (M.-A.A.)

* Correspondence: rebeka.anna.rap@gmail.com

Received: 7 August 2020; Accepted: 11 September 2020; Published: 15 September 2020

\begin{abstract}
In the 21st century, green consumption has risen into a global trend, which inclines cosmetic companies to be more environmental-friendly and to have a larger green product portfolio to satisfy these new consumers' needs. Social media contributed to this trend, shaping consumers' attitudes into more environmentally conscious behavior. The present study applied the Theory of Planned Behavior (TPB) to explain the impact of Social Media on consumers' purchase intention and motivation (altruism and egoism). Based on empirical investigation, an online survey was developed to measure the proposed conceptual model. The reliability and validity of the reflective constructs were tested using partial least squares (PLS) modeling technique. The results indicate the importance of social media on consumers' attitudes, subjective norms, altruistic and egoistic motivations, and the impact of these variables as the antecedents of green cosmetics purchase intention. These results have important theoretical implications. They revealed that external factors such as social media as an information source, have an important role in consumer motivation formation and green cosmetic purchasing intentions. The findings are relevant for marketers to implement better communication strategies on social media to increase consumers' motivations and purchase intention toward green cosmetics.
\end{abstract}

Keywords: theory of planned behavior; green cosmetics; altruism; egoism; social media; purchase intention

\section{Introduction}

The environmental movement has greatly changed consumer behavior and environmental awareness [1], resulting in an increased demand for green products [2]. The green behavior and benefits boost the loyalty not only in the case of the products and brands, but also towards the different retail formats [3,4]. Thus, environmental issues have become a frequent topic among consumers and more consumers have recognized the consequences of the effects of consumption on the environment [5]. This environmental activism inclines companies to develop and produce more environmentally friendly products, which are less harmful to the environment. The companies can opt for an entirely green product portfolio or for a mix of green and traditional product lines [6]. In the last two years, the global cosmetics industry produced an annual growth rate above $5 \%$, reaching 500 billion U.S. dollars market value in 2019 [7]. The cosmetics industry has responded to consumer trends with a wide range of products and preparations for healthier lifestyles and green beauty products [8]. In a worldwide survey about the importance of green features in cosmetic products, $64 \%$ of the women preferred organic ingredients, $60 \%$ sustainable features, and $52 \%$ vegan ingredients in cosmetics selection [9]. Although the concept of green cosmetics has become mainstream among companies and consumers, especially on social media, there is not a uniform and formal definition of green cosmetics. Nonetheless, 
the present study defines green cosmetics by the following: in addition to their essential functions, they aim to protect the environment, minimize pollution, use renewable resources responsibly, and protect animal welfare and species [10].

Liobikiene and Bernatoniene [11] argue that factors drive the purchase of the different green product types differently (e.g., organic food, cosmetics, durable goods, luxury). Based on an extensive literature review, they proposed a special model for green cosmetics, differentiating even between personal care and color cosmetic (attributed to luxury category) products. Consequently, internal, social and external factors should be considered in studying both for personal care products and color cosmetics. However, in the case of personal care, particular attention should be paid to health consciousness while in case of color cosmetics, the brand and quality are determinant factors [11]. Most studies explain green cosmetic purchasing through internal (environmental attitude, values, etc.) and social factors (social pressure, etc.). The effect of external factors (environmental information, price, etc.) on green cosmetic purchasing are less explored. Chin et al. [12] found that perceived authority support has a significant effect on buying intention [12]. Murwaningtyas et al. [13] revealed that celebrities on Instagram influence green cosmetics purchase intention [13]. The role of external factors on green cosmetic purchasing intention is not conclusive yet, because Ma et al. [14] did not find significant influence of external variables (such as fashion trend, media impact, quality concern, wastes and recycling, social pressure) [14]. The present study aims to extend the literature regarding the role of external factors in green cosmetics related to the source of information such as social media.

Nowadays, social media plays a critical role in shaping consumer opinions, influencing attitudes, and purchasing decisions [15]. Social media's impact on consumers' green behavior and purchase intention has been studied by several scholars, including in the cosmetic market. Social networks can promote and sustain environmental behavior [16], and celebrities on social media can shape consumers' attitudes toward green cosmetics [13]. Social media has become an important communication channel for creating content, sharing ideas, and expressing opinions and information [17]. Social media has revolutionized the communication between consumers and companies, including green products, and allowed consumers to have a more interactive buying experience [18]. Consumers primarily use social media to obtain information about products [19]. In the cosmetics industry, the social media platform became an important communication platform. According to global study conducted in 2019, $37 \%$ of the consumers discovered online beauty brands by seeing ads in social media, $33 \%$ by following recommendations and comments in social media, $22 \%$ rely on posts from expert bloggers, $22 \%$ follow the brands' social media page, and $22 \%$ get information on new products via celebrity endorsements in social media [7]. Therefore, investigating the impact of social media on behavior formation is an emerging topic.

When it comes to purchase intention research, studies extensively rely on the Theory of Planned Behavior (TPB), where attitude toward the action, social norm and perceived behavioral control determine the formation of the purchase intention [20]. Since green behavior is a relatively new concept, additional variables are needed in order to describe more properly the impact of social media on green cosmetics purchase intention. The motivations for purchasing green products are a critical aspect of ethical consumption in the literature, highlighting the importance of altruistic and egoistic motivations. Altruism reflects a selfless behavior, e.g., a concern for the environment, while egoism indicates a concern for one's own health or the health of one's own family [21]. Previous studies noted that both environmental and health concern have positively influenced consumers attitudes toward green cosmetics [21,22].

Despite the literature showing great interest towards the buying intention formation of green products, little attention has been paid to the role of social media in this process. The present research aims to fill this gap in the literature by examining the impact of social media on consumers' altruistic and egoistic motivation, attitude and subjective norms toward green cosmetics, as well as outlining the antecedents of consumers' purchasing intentions. The present study proposes a research model based on the Theory of Planned Behavior with prediction of purchase intention as the central element [20]. 
The originality of the study stands in the exploring how the social media impacts the purchase intention through motivations, attitude and subjective norm.

In what follows, the paper presents the review of the literature and the hypotheses development; the description of the research methodology; the research results and discussion and theoretical and managerial conclusion, also highlighting the limitations and future research perspectives.

\section{Review of the Literature and Hypothesis Development}

The Theory of Planned Behavior (TPB) is a widely used socio-cognitive model aimed at explaining the variance of voluntary behavior. At the center of the model is the intention to purchase, which is listed as a kind of motivational factor to perform specific behaviors [20]. Based on the TPB, the intention to implement a particular behavior is influenced by attitude towards behavior, subjective norms, and perceived behavioral control [23]. Attitude is a positive or negative belief, an opinion on a particular behavior [20]. According to Ajzen [24], an individual is more likely to behave in a certain way if he or she has a positive attitude towards that particular behavior. The subjective norm is an individual's engagement to a specific behavior due to perceived behavioral expectations and social pressure. The perceived behavioral control indicates whether a person's motivation is influenced by how he or she perceives the level of difficulty or simplicity of a particular behavior [20].

The TPB model is widely used to investigate the intention to purchase green products [25-27]; organic food [27-29], recycling behavior [30] and zero waste lifestyle adoption [31]. As specified earlier, the TPB is broadly used to examine the intention to buy green products, including the cosmetics market. Ahmad and Omar [32] found that for Generation Z, the main reason for buying natural cosmetics is the distinction from their peers, while environmental concerns are not a priority for these consumers. Kim and Seock's [33] disagreed with this approach and claimed that environmental concerns affect consumers' willingness to buy green cosmetics. Kim et al. [34] suggest that all TPB variables have significant impact on the intention to purchase green cosmetic products, which has been supported by other authors [12,35-37]. Consumers' prior experiences with other organic products have a positive influence on their willingness to purchase organic cosmetics [38]. Ma, Rau and Guo [14] noted that environmental awareness affects the intention to buy green makeup.

Previous studies have found a positive relationship between environmentally conscious attitudes and green buying behavior [39], although some research has shown a weak relationship between those two variables (e.g., Eze and Ndubisi [40]). According to Yazdanpanah and Forouzani [27], the main explanatory factor for buying organic products was attitude, while the perceived control and subjective norm did not influence the purchase. The positive impact of attitudes towards green cosmetic products on buying intention has been supported by several studies $[22,35,36,38,41]$. Based on the above discussion, we assume that:

Hypothesis 1 (H1). Attitude positively influences consumers' purchasing intention towards green cosmetics.

Consumers often purchase different products not to satisfy their own needs, but to influence social needs, establish and maintain social relationships, and achieve other social functions such as social status [42]. Vermeir and Verbeke [43] found a positive relationship between social pressure and attitude towards buying sustainable products, as supported by similar studies [38]. Gupta and Ogden [44] found that the majority of green consumers have a high level of trust in others and expect others to participate in green behavior as well. Thus, consumers often buy green products to show their ecological concerns to society. Several studies have shown that social norms are positively correlated with the intention and actual purchase of green products [40,43]. Tan and Lau [45] highlighted that the most important determinant in attitudes towards a green product was the personal norm. White et al. [46] conclude that in the case of sustainable actions where the outcomes are abstract for the consumers (e.g., distant future intangible benefits), the social factor will have a higher impact on the 
behavior. Regarding green cosmetics, the positive impact of the subjective norm on the intention to buy green products has also been demonstrated $[12,35,36,38]$. Therefore, we assume that:

Hypothesis 2 (H2). Subjective norms positively influence consumers purchasing intention towards green cosmetics.

Since its appearance, the TPB has been applied in many contexts and scenarios, each author adding new variables to the model upon their specific research aims. Thus, in the case of research undertaken in environment-related context, the consumers' environmental and health concerns are frequently investigated. Environmental concern can be viewed as a reflection of altruistic values [21], which focuses on protecting the natural environment without any benefit for one's self [47]. Egoistic value reflects the individual's concern for their own health or the health of their family [21].

Altruism can be defined as a selfless behavior by an individual that benefits others [48]. Previous studies found a positive relationship between consumers' environmental concerns and attitudes towards buying organic food [49]. Consumers express their pro-environmental behavior and concern for nature via purchasing organic food [50] and green products [51]. The positive impact of environmental concern on attitude has been studied in several contexts, e.g., organic food [52] and green products [53]. Preexisting altruistic values have a stronger influence on attitude than egoistic values toward eco-friendly packaged products [19]. In the context of green cosmetics, Kim and Chung [38] found that consumers' environmental consciousness has a positive impact on the attitude towards buying organic personal care products and it is an important predictor for green purchase intention of cosmetics. Fauzi et al. [54] noted that environmental consciousness significantly influences consumers' attitudes towards buying green cosmetics and skincare products. Based on these, we assume that:

Hypothesis 3 (H3). Altruistic motivation (environmental concern) positively influence consumers' attitudes towards green cosmetics.

Previous studies noted that consumers' health concerns can have a positive effect on attitude towards green products $[55,56]$. Health-related topics and attributes are considered to be motivating factors for purchasing green products [57]. Some studies indicate that egoistic values cannot be associated with pro-environmental behavior, hence altruistic values suggest that behavior [58]. Magnusson et al. [59] found that consumers' concerns about their own and their family's health positively influence attitude toward organic food. In the case of personal care products, Ghazali et al. [22] found that health value has a significant positive impact on consumer attitude. Kim and Chung [38] mentioned that health consciousness is rather important for the attitude towards buying organic shampoo and body lotion. On the contrary, Fauzi et al. [54] noted that health consciousness significantly influences consumers' attitudes towards green cosmetics. Therefore, we derive the following hypotheses:

Hypothesis 4 (H4). Egoistic motivation (health concern) positively influence consumers' attitudes towards green cosmetics.

Li, Lee and Lien [60] found that messages on social media increase consumers' willingness to buy, while interactions on social media directly influence purchasing decisions by encouraging consumers to resemble their peers [61]. Social media has a broad influence on consumers' attitudes, perceptions, and purchasing decisions through each stage of purchase decisions [15]. Social media is perceived as useful and trustworthy by consumers [62]. However, the perceived usefulness of sponsored advertising on Facebook is negatively affected by intrusiveness and privacy concerns [63]; therefore, it should be used carefully. Social media was found to be a critical success factor to promote responsible entrepreneurship (e.g., CSR reporting) by SMEs for stakeholders [64]. Consumers' social media activity positively influences pro-environmental behaviors such as reducing, reusing and recycling 
wasteful materials [31]. Consumers are more likely to trust green brands through frequent and positive experiences published on social media [65]. According to Bedard and Tolmie [66], social media usage has a positive impact on green purchase intention, also on consumers' green buying behavior [67]. Murwaningtyas et al. [13] found that the reliability, expertise, and attractiveness of celebrities have a positive impact on consumers' advertising attitudes and intentions to purchase organic cosmetics through Instagram. Social networks sustain, encourage, and disseminate the norm of environmental behavior [16]. Therefore, we assume that:

Hypothesis 5 (H5). Social media positively influence consumers' attitude towards green cosmetics.

Hypothesis 6 (H6). Social media positively influence consumers' subjective norms towarsd green cosmetics.

Altruistic and egoistic motivations are frequently studied factors in the context of information sharing in social media. According to Oh [68], altruism is the most important motivation for users to share information and help others (in, e.g., answering a question) on social media. Egoism is also an influential motivation for receiving and sharing ideas and information. According to Hsu and Lin [69], enjoyment has a positive impact on attitude toward blogging. Consumers are highly influenced by their peers and by other opinions [70] in their behavior and decision making. Suki and Suki [71] found that social values are the most influential factors in consumers' environmental concern in the case of green products. Holbert et al. [72] found that television news and nature documentaries positively influence consumers' desires to purchase environmentally friendly products. Moreover, social media can contribute to consumers' environmental consciousness behavior [73]. It has been found that social media influencers can successfully address the lack of awareness of their followers by systematic informational messages regarding a green lifestyle adoption [74]. The power of social media in altruistic and egoistic motivation formation is indisputable. Chwialkowska [74] found that social media influencers present the personal benefits of the green lifestyle decisions (personal heath, effectiveness, savings, etc.) rather than the environmental issues. On the other hand, Min et al. [75] revealed how influential Instagram and Twitter can be in the spread of the animal testing issues in the cosmetic industry. Therefore, the following hypotheses have been formulated:

Hypothesis 7 (H7). Social media has a positive impact on consumers' altruistic motivation regarding green cosmetics.

Hypothesis 8 (H8). Social media has a positive impact on consumers' egoistic motivation regarding green cosmetics.

Figure 1 encompasses the conceptual model proposed for research and the hypotheses.

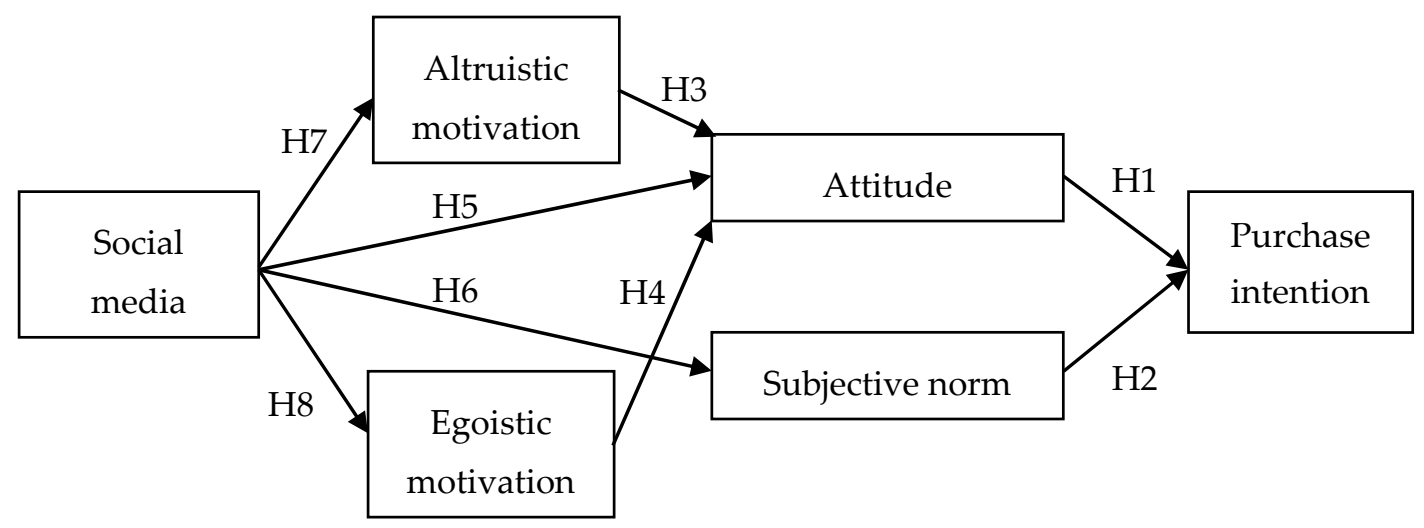

Figure 1. Conceptual model. 


\section{Materials and Methods}

\subsection{Research Design and Sample}

The present study proposes to explore the impact of social media on consumers' green cosmetics purchase intentions. A conceptual model (Figure 1) was developed to test the proposed hypotheses, which is based on the theory of planned behavior, to analyze the impact of social media on consumers' altruistic and egoistic motivations, as well as attitude toward green behavior and subjective norms; also to test the impact of TPB variables on consumers green cosmetics purchase intention.

Based on empirical investigation, this study uses a quantitative survey through a self-administered questionnaire in Romania and Hungary. The data collection was implemented between March 10th and April 24th 2020 using a virtual snowball sampling technique through social network sites, such as specified Facebook groups dedicated to green, natural, and organic cosmetic consumer users. The population of this study consisted of women who are active social media users and have at least heard about the term green cosmetics. According to Zelezny et al. [76] women are more likely to adopt green behavior and are more likely to purchase green products than men $[77,78]$. The socio-demographic characteristics of the 180 respondents are presented in Table 1 . Overall, $75 \%$ of the respondents have heard of the term green cosmetics and $92 \%$ of those who were aware, used green cosmetics. They mostly use facial green care products $(65.3 \%)$, such as hydrant face cream and green hair care products $(53.2 \%)$.

Table 1. Demographic characteristics of the respondents.

\begin{tabular}{|c|c|c|c|}
\hline Demographics & & Frequency & Relative Frequency \% \\
\hline \multirow{3}{*}{ Age $(N=180)$} & Over 40 & 47 & 26.1 \\
\hline & $26-39$ & 56 & 31.1 \\
\hline & Below 25 & 77 & 42.8 \\
\hline \multirow{4}{*}{ Education level $(\mathbf{N}=180)$} & High School or below & 34 & 18.9 \\
\hline & Currently attending university & 43 & 23.9 \\
\hline & Bachelor's Degree & 68 & 37.8 \\
\hline & Master's Degree and PhD & 35 & 19.4 \\
\hline \multirow{4}{*}{ Occupation $(\mathrm{N}=180)$} & Student & 55 & 30.6 \\
\hline & Employee & 92 & 51.1 \\
\hline & Entrepreneur & 26 & 14.4 \\
\hline & Non-workers (unemployed and retired) & 7 & 3.9 \\
\hline \multirow{2}{*}{ Country $(N=180)$} & Romania & 153 & 85.0 \\
\hline & Hungary & 27 & 15.0 \\
\hline
\end{tabular}

\subsection{Questionnaire Design and Measures}

The questionnaire comprises of seven major sections: social media searching behavior (four items), altruistic motivation (four items), egoistic motivation (two items), attitude toward green cosmetics (three items), subjective norms (three items), purchase intention for green cosmetics (four items) and demographic variables. The beginning of the questionnaire was meant to clarify the concept of cosmetics according to Regulation (EC) No 1223/2009 of the European Parliament and of the Council. The measurements of each variable were developed according to the literature and previous research (Table 2), and modified in the context of the present study. A seven-point Likert scale was used (1-total disagreement/7-total agreement). 
Table 2. Measurement of the reflective constructs.

\begin{tabular}{|c|c|c|c|}
\hline Construct & Item & Measure & Source \\
\hline Social media (SM) & $\begin{array}{l}\text { SM1 } \\
\text { SM2 } \\
\text { SM3 } \\
\text { SM4 }\end{array}$ & $\begin{array}{l}\text { My engagement on social media influences my green cosmetic } \\
\text { purchase. } \\
\text { I use SM to search information about green cosmetic products. } \\
\text { Contents about green cosmetics on SM are trustworthy. } \\
\text { Contents about green cosmetics on SM are believable. }\end{array}$ & {$[79,80]$} \\
\hline Altruistic motives (AL) & $\begin{array}{l}\text { AL1 } \\
\text { AL2 } \\
\text { AL3 } \\
\text { AL4 }\end{array}$ & $\begin{array}{l}\text { Buying this green cosmetic brand has an ethical interest for } \\
\text { me, considering that the products have been ecologically } \\
\text { produced. } \\
\text { The environmental preservation of this green cosmetic brand } \\
\text { is coherent with my ethical values. } \\
\text { Humans must maintain the balance with nature in order to } \\
\text { survive. } \\
\text { While purchasing cosmetics products, I focus on } \\
\text { environmentally friendly cosmetics. }\end{array}$ & [81-83] \\
\hline Egoistic motives (EG) & $\begin{array}{l}\text { EG1 } \\
\text { EG2 }\end{array}$ & $\begin{array}{l}\text { I consider myself as a health-conscious consumer. } \\
\text { I think air pollution by industry is dangerous for me and my } \\
\text { family. }\end{array}$ & {$[84,85]$} \\
\hline Attitude (AT) & $\begin{array}{l}\text { AT1 } \\
\text { AT2 } \\
\text { AT3 }\end{array}$ & $\begin{array}{l}\text { For me, using the green cosmetic is wise. } \\
\text { I like green cosmetic products. } \\
\text { I feel proud when I buy/use green cosmetic products. }\end{array}$ & $\begin{array}{l}{[12]} \\
{[86]}\end{array}$ \\
\hline Subjective norms (SN) & $\begin{array}{l}\text { SN1 } \\
\text { SN2 } \\
\text { SN3 }\end{array}$ & $\begin{array}{l}\text { Specialists recommend that I use green cosmetic products. } \\
\text { Persons important to me would prefer that I use green } \\
\text { cosmetic products. } \\
\text { My family and close friends want me to use green cosmetic } \\
\text { products. }\end{array}$ & [12] \\
\hline Purchase intention (PI) & $\begin{array}{l}\text { PI1 } \\
\text { PI2 } \\
\text { PI3 } \\
\text { PI4 }\end{array}$ & $\begin{array}{l}\text { I am likely to buy green cosmetic products. } \\
\text { I will buy green cosmetic products as soon as I run out of the } \\
\text { cosmetic products I am currently using. } \\
\text { I will recommend green cosmetic products to other people. } \\
\text { I will tell other persons about the green cosmetic brand. }\end{array}$ & [12] \\
\hline
\end{tabular}

\section{Results}

The proposed hypotheses and the conceptual model (Figure 1) were tested using partial least square (PLS) modelling, a variance-based structural equation modelling method. It is useful to test complex models based on a smaller dataset. The PLS is less restrictive than other models regarding the sample size, data distribution and the complexity of the model [87]. For the data analysis, the SmartPLS 3.0 software was used, which first examines the reliability of the scales and then establishes the relationship between the constructs of the research model.

Confirmatory factor analysis was used to test the reliability and validity (factor loadings, evaluations of the internal consistency reliability, convergent validity and discriminant validity) of the reflective constructs: social media (SM), altruistic motivation (AL), egoistic motivation (EG), attitude (AT), subjective norm (SN) and purchase intention (PI). The factor loading of all items was higher than 0.7 (Table 3), supporting the convergent validity of the constructs [88]. Cronbach's $\alpha$ was used to test the reliability of the constructs, the value of which was greater than 0.7 in all cases, reflecting the internal consistency of the scale and the competency for confirmatory purposes [89]. The Average Variance Extracted (AVE) values were above 0.5, indicating the convergence validity of the constructs [90]. According to Hair et al. [88], the composite reliability (CR) should be higher than 0.7 , which indicates the reliability of the results. 
Table 3. Scale reliability.

\begin{tabular}{|c|c|c|c|c|c|}
\hline Constructs & Items & Loading $(>0.7)$ & Cronbach's Alpha (>0.7) & $\begin{array}{c}\text { AVE } \\
(>0.5)\end{array}$ & $\begin{array}{c}\mathrm{CR} \\
(>0.7)\end{array}$ \\
\hline \multirow{4}{*}{ Social media (SM) } & SM1 & 0.818 & \multirow{4}{*}{0.925} & \multirow{4}{*}{0.819} & \multirow{4}{*}{0.947} \\
\hline & SM2 & 0.904 & & & \\
\hline & SM3 & 0.945 & & & \\
\hline & SM4 & 0.946 & & & \\
\hline \multirow{4}{*}{ Altruistic motives (AL) } & AL1 & 0.771 & \multirow{4}{*}{0.764} & \multirow{4}{*}{0.586} & \multirow{4}{*}{0.849} \\
\hline & AL2 & 0.832 & & & \\
\hline & AL3 & 0.723 & & & \\
\hline & AL4 & 0.731 & & & \\
\hline \multirow{2}{*}{ Egoistic motives (EG) } & EG1 & 0.854 & \multirow{2}{*}{0.721} & \multirow{2}{*}{0.780} & \multirow{2}{*}{0.876} \\
\hline & EG2 & 0.911 & & & \\
\hline \multirow{3}{*}{ Attitude (AT) } & AT1 & 0.871 & \multirow{3}{*}{0.825} & \multirow{3}{*}{0.742} & \multirow{3}{*}{0.896} \\
\hline & AT2 & 0.824 & & & \\
\hline & AT3 & 0.887 & & & \\
\hline \multirow{3}{*}{ Subjective norms (SN) } & SN1 & 0.822 & \multirow{3}{*}{0.739} & \multirow{3}{*}{0.651} & \multirow{3}{*}{0.848} \\
\hline & SN2 & 0.834 & & & \\
\hline & SN3 & 0.763 & & & \\
\hline \multirow{4}{*}{ Purchase intention (PI) } & PI1 & 0.810 & \multirow{4}{*}{0.891} & \multirow{4}{*}{0.755} & \multirow{4}{*}{0.925} \\
\hline & PI2 & 0.901 & & & \\
\hline & PI3 & 0.898 & & & \\
\hline & PI4 & 0.865 & & & \\
\hline
\end{tabular}

Table 4 illustrates the discriminant validity by the Fornell-Larcker criterion. The root square of the AVE values for each latent variable must be greater than the correlation coefficient between that latent variable and all other latent variables [91], so all constructs are appropriate indicating discriminatory validity.

Table 4. Discriminant validity.

\begin{tabular}{ccccccc}
\hline Constructs & AL & AT & EG & PI & SM & SN \\
\hline AL & $\mathbf{0 . 7 6 5}$ & & & & & \\
AT & 0.501 & $\mathbf{0 . 8 6 1}$ & & & & \\
EG & 0.405 & 0.401 & $\mathbf{0 . 8 8 3}$ & & & \\
PI & 0.504 & 0.399 & 0.229 & $\mathbf{0 . 8 6 9}$ & & \\
SM & 0.415 & 0.388 & 0.218 & 0.368 & $\mathbf{0 . 9 0 5}$ & \\
SN & 0.222 & 0.192 & 0.069 & 0.542 & 0.408 & $\mathbf{0 . 8 0 7}$ \\
\hline
\end{tabular}

To test the hypotheses, a bootstrap procedure was applied, using 5000 subsamples. Figure 2 presents the results of the SEM-PLS algorithm and the relations between the elements of the model. Based on the t-statistics, seven hypotheses are accepted with a positive and significant impact, while $\mathrm{H} 4$ (egoistic motivation and attitude) was rejected. 


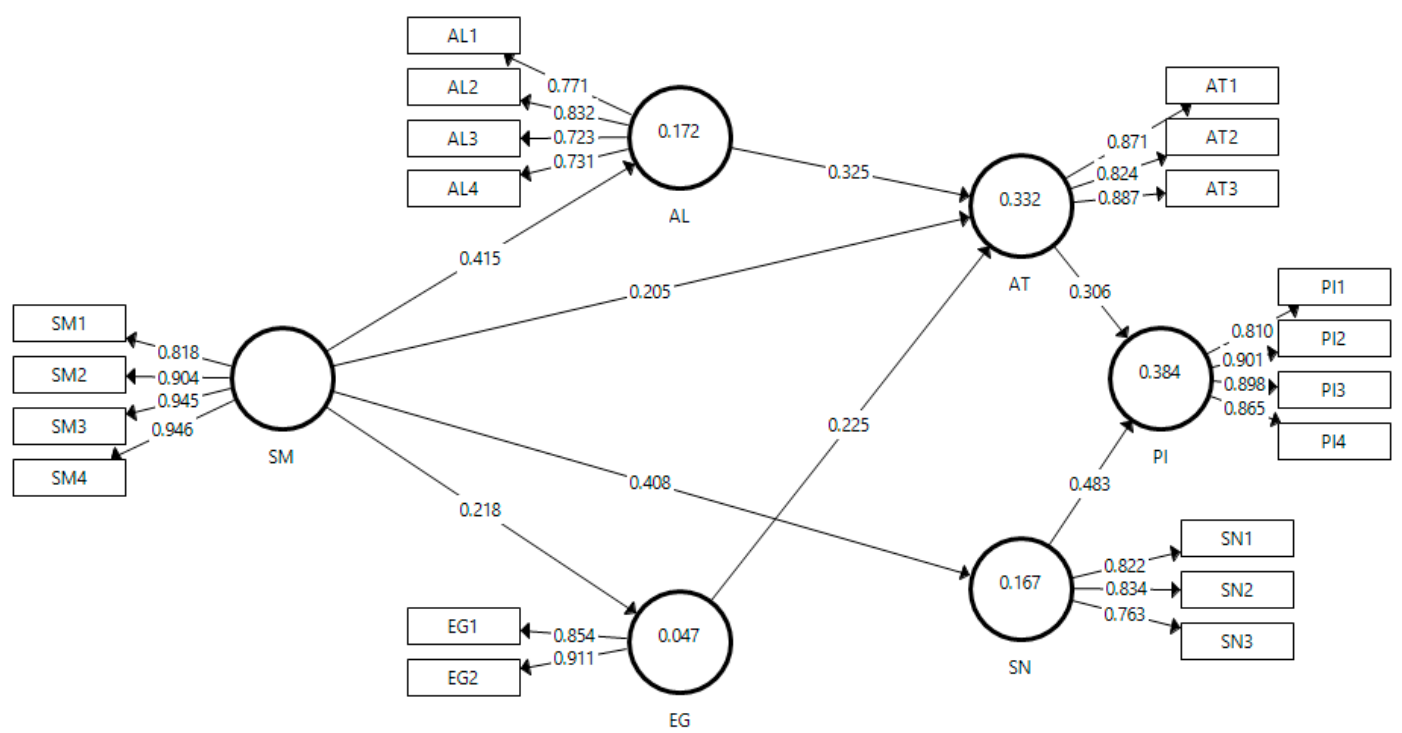

Figure 2. The structural model.

Regarding the basic TPB model elements, $\mathrm{H} 1$ assumed that attitude positively influences green purchase intention. Based on the t-statistics and path coefficients, there is a positive relationship between attitude and purchase intention toward green cosmetics $(\beta=0.306 ; \mathrm{t}=3.942$ and $p<0.001)$, hence H1 is accepted. This is in line with several studies reported in the field of green cosmetics $[22,35,36,38,41]$. The results of Table 5 indicate that subjective norms have a positive and significant impact on consumers' purchase intentions towards green cosmetics $(\beta=0.483 ; t=6.224$ and $p<0.001)$; therefore, $\mathrm{H} 2$ is supported. Similar results have been reported in several previous studies conducted in green cosmetics $[12,35,36,38]$.

Table 5. The path coefficients of the structural equation model.

\begin{tabular}{cccccc}
\hline Paths & $\begin{array}{c}\text { Path } \\
\text { Coefficients }\end{array}$ & $\begin{array}{c}\text { Standard } \\
\text { Deviation }\end{array}$ & T-Value & $\boldsymbol{p}$-Value & Hypotheses \\
\hline $\mathrm{AT} \rightarrow \mathrm{PI}$ & 0.306 & 0.078 & $3.942^{* * *}$ & 0.000 & H1-Supported \\
$\mathrm{SN} \rightarrow \mathrm{PI}$ & 0.483 & 0.078 & $6.224^{* * *}$ & 0.000 & H2-Supported \\
$\mathrm{AL} \rightarrow \mathrm{AT}$ & 0.325 & 0.102 & $3.181^{* *}$ & 0.001 & H3-Supported \\
$\mathrm{EG} \rightarrow \mathrm{AT}$ & 0.225 & 0.127 & 1.769 & 0.077 & H4-Not supported \\
$\mathrm{SM} \rightarrow \mathrm{AT}$ & 0.205 & 0.102 & $2.001^{*}$ & 0.045 & H5-Supported \\
$\mathrm{SM} \rightarrow \mathrm{SN}$ & 0.408 & 0.077 & $5.324^{* * *}$ & 0.000 & H6-Supported \\
$\mathrm{SM} \rightarrow \mathrm{AL}$ & 0.415 & 0.083 & $4.977^{* * *}$ & 0.000 & H7-Supported \\
$\mathrm{SM} \rightarrow \mathrm{EG}$ & 0.218 & 0.081 & $2.681^{* *}$ & 0.007 & H8-Supported \\
\hline
\end{tabular}

Note: ${ }^{*} p<0.05 ;{ }^{* *} p<0.01 ;{ }^{* * *} p<0.001$; $\mathrm{SM}=$ social media; $\mathrm{AL}=$ altruism; $\mathrm{EG}=$ egoism; $\mathrm{AT}=$ attitude; $\mathrm{SN}=$ subjective norm; $\mathrm{PI}=$ purchase intention.

$\mathrm{H} 3$ assumed that altruism has a positive impact on the attitude toward green cosmetics. The results of Table 5 indicate a positive relationship between altruistic motivation and green attitude, hence $\mathrm{H} 3$ is supported $(\beta=0.325 ; t=3.181$ and $p<0.01)$. This supports the findings of previous studies conducted in fields of organic personal care products $[38,54]$. Based on the analysis, egoistic motivations have an insignificant impact on consumers' green attitudes, therefore $\mathrm{H} 4$ is rejected $(\beta=0.225 ; \mathrm{t}=1.769$ and $p>0.05)$. This is in line with previous results $[38,54]$ and contrary to the findings conducted by Ghazali et al. [22].

Regarding the influence of social media, Table 5 indicates that social media has a significant positive impact on consumers' attitudes towards green cosmetics $(\beta=0.205 ; \mathrm{t}=2.001$ and $p<0.05)$. Hence, $\mathrm{H} 5$ can be supported. Similar findings have been reported previously in the literature [13]. In the second hypothesis, $\mathrm{H} 6$ assumed that social media has a positive impact on subjective norms. According to the results (Table 5), social media positively influenced consumers' subjective norms 
regarding green cosmetics $(\beta=0.408 ; \mathrm{t}=5.324$ and $p<0.001)$, which is also line with the results of previous similar studies [16]. H7 concludes that social media has a positive impact on consumers' altruistic motivations. The analysis emphasizes a positive relationship between social media and the altruistic motivation of consumers towards green cosmetics $(\beta=0.415 ; \mathrm{t}=4.977$ and $p<0.001)$. This suggests that social media can shape consumers' environmental concerns, which confirms the results of the studies in the fields of green products [71,73]. Finally, H8 presumed that social media has a positive impact on egoistic motivation. Based on the $t$-statistics, social media positively influences consumers egoistic motivations toward green cosmetics $(\beta=0.218 ; t=2.681$ and $p<0.01)$. This indicates that social media has a positive impact on consumers' health concern regarding green cosmetics.

The goodness of fit for the model was satisfactory with a square root mean residual (SRMR) of 0.08, which is equal to the recommended 0.08 maximum [92], in the case of saturated model. However, the estimated model's SRMR $=0.1$ indicates that the model needs further refinement and testing. Moreover, the NFI $=0.722$ does not fit the minimum criteria [93]; that is, the model might be ill-specified. The reason could be the limited sample size of $n=180$, and the large number of the observed variables. Overall, the subjective norm and the attitude explain $38.4 \%$ of the variance of green cosmetics purchase intention $\left(R^{2}=0.384\right)$, altruistic and egoistic motivation and the social media explain $33.2 \%$ of the variance of the attitude $\left(R^{2}=0.332\right)$, representing a moderate predictive power of the model, and exceeding in all cases the minimum criteria of 0.25 [94]. Social media also has a direct positive impact on altruistic motivation and the subjective norm. The effect sizes of the relations $\left(\mathrm{f}^{2}\right)$ vary from 0.05 to 0.365 . Weak effect sizes $\left(0.02<\mathrm{f}^{2}<0.15\right)$ can be reported in the case of altruistic motivation $\left(\mathrm{f}^{2}=0.114\right)$, egoistic motivation $\left(f^{2}=0.063\right)$ and social media activity $\left(f^{2}=0.052\right)$, impacts on attitude toward green cosmetics, the social media effect on egoistic motivations $\left(\mathrm{f}^{2}=0.050\right)$, and attitudes' impacts on purchase intentions $\left(\mathrm{f}^{2}=0.146\right)$. Moderate effect size $\left(0.15<\mathrm{f}^{2}<0.35\right)$ can be reported in the case of the social media activity on altruistic motivation $\left(f^{2}=0.208\right)$ and on the subjective norms $\left(f^{2}=0.200\right)$. Finally, a strong effect $\left(f^{2}>0.35\right)$ can be reported in the case of social norms on green cosmetics purchase intentions $\left(\mathrm{f}^{2}=0.365\right)$ [95].

\section{Discussion}

The present study explores the impact of social media on green cosmetics purchase intentions through motivations, attitude, and subjective norm as the antecedents of purchase intention. This study contributes to the literature by examining and supporting the effects of the TPB variables, attitude, and subjective norms on green buying intentions, and exploring the motivational factors of the green attitude. The innovativeness of the research is in introducing the influence of social media on elements of TPB and on the formation of altruistic and egoistic motivations in the case of green cosmetic products.

Empirical findings indicate that attitude and subjective norm have a positive impact on the purchase intention of green cosmetics. Results also show that social media has multiple impacts on buying intention formation. First, social media plays a significant role in the formation of consumers' attitude and subjective norms, and there is an indirect effect between social media and purchase intention toward green cosmetics. According to responses, consumers' engagement on social media can influence their cosmetic purchasing decision while perceiving the information on social media trustworthy and believable. The results are in line with the work of Murwaningtyas et al. [13], which focuses on the impact of celebrity endorsers through social media on organic cosmetics purchase intentions. Their findings suggest that celebrities on Instagram positively influence the attitude towards advertisement and organic purchase intention. Moreover, Lee [16] noted that social influence was the main influential factor for green purchasing behavior in the context of Hong Kong adolescents. Although the previous research was conducted in different contexts from the present study, they overlap with the current results. Furthermore, social media has a significant impact on consumers' altruistic and egoistic motivations. Social media can influence consumers' environmental concerns, for instance in the motivation to buy cosmetics which are less harmful to the environment. Moreover, social media has a positive impact on consumers' egoistic motivations, meaning that social media can 
influence consumers' health concerns regarding green cosmetics, in order to choose cosmetics which are positive for their own health. Despite the fact that Suki and Suki [71] did not conduct an investigation on an online platform such as social media, they find that social influence has the most powerful impact on consumers' environmental concern regarding green products, which is supported also by Zahid et al. [73]. Egoistic motivations (health concern) do not influence consumers' attitudes toward green cosmetics, but altruistic motivations (environmental concern) do. These results support the work of Kim and Chung [38], who also find that health consciousness is not a predictor for consumers' purchasing intentions regarding organic personal care products, while environmental consciousness is. This result was supported by Fauzi et al. [54], who noted that only environmental consciousness influences generation $X$ purchase intention towards green cosmetics. The findings contrasted with those of Ghazali et al. [22], who highlighted that health values influence consumers' attitudes toward re-purchasing organic care products. It can be concluded that consumers' motivations for purchasing green cosmetics are still unclear, and there are several findings in the literature which are in contradiction. For this reason, future research needs to investigate this gap in the literature.

\section{Conclusions}

Green cosmetics are receiving an increasing interest on behalf of the consumers; however, the formation of the attitude and motivations towards these products is still an open research topic in the literature. Even so, lately, social media has radically changed the nature of the communication between both the company and consumers, and the consumers themselves. The results of the present study contribute to the theory by investigating the impact of social media on consumers' motivations and purchase intentions towards green cosmetics. Based on a TPB model, the present study extends the green cosmetics literature by revealing the role of external factors on consumers' motivations and purchasing intentions. The results reinforce the predictive power of attitude and subjective norm on purchase intention for green cosmetics, confirm the impact of altruistic motivation on attitude, and extend the model with the effect of the social media as an information source for the formation of these antecedents. Thus, the present research provides a better understanding and a good starting point for further research on how social media can impact consumers' buying intentions. According to present research, social media influences the attitude toward green cosmetics, the subjective norm, and also impacts the formation of both altruistic and egoistic values of the consumers.

The findings of the present study are also relevant for marketers and managers, as they provide valuable information about consumers' intentions to purchase green cosmetics and relevant factors that may influence this behavior. The results highlighted that social media can increase consumers' environmental concerns, which in turn determine a positive attitude toward green cosmetics. Thus, social media is a powerful vehicle for altruistic messages, and can be an important channel of sensitization towards environmental issues and motivation of pro-environmental behavior. These messages can be later translated into positive attitudes, and then into a purchase intention towards green cosmetic brands. The effect of social media on health concerns was proved, but with no further impact on green attitude, for the simple reason that the information on social media regarding green cosmetics focuses on environmental issues rather than health issues. For example, there are highly exposed green issues such as cruelty-free cosmetics [75] or the negative public opinion on massive deforestation for obtaining palm-oil, a basic component for many cosmetic products [96]. Thus, consumers associate their green cosmetics orientation with pro-environmental motivations, and they do not feel that the egoistic motives outcomes (linking and buying green cosmetics) can also converge with environmental benefits. Nowadays, social media is not only a communication channel, but can also influence the consumers' behavior and purchasing decisions through multiple mechanisms. For this reason, companies need to provide more informational materials on the concept of green cosmetics. The green concept is a multidimensional one, it can denote the product development, ingredients, supplying, packaging, consuming and discarding issues. Different social media communication tools can cover all these dimensions and benefits. 
Besides, social media can influence the reference groups of the consumers, generating social pressure (in, e.g., families) which directly influences the purchase intention towards green cosmetics. Thus, celebrities' and influencers' posts, content shared by friends, family members, thematic group discussions, and reviews should be considered as effective means for creating awareness and positive attitudes towards green brands. Based on these findings, companies can develop their messages on social media platforms, emphasizing the environmental benefits of their products in order to enhance the positive attitude and perceived social pressure in a green cosmetics buying context.

Finally, there are several limitations to the research which needs to be taken into account. As the number of samples was relatively low $(n=180)$, the present research can be seen as exploratory, and in need of further testing and confirmation. The structural model should be treated carefully, as the fit indices did not return a consistent validity of the inner model. As can be seen in the literature review, green buying intention and behavior are influenced by several factors. Since the predictive power of the model is moderate in the present research, for future research, it is recommended to examine the effects of other internal (e.g., trust) and external (e.g., product benefits, price, brand) factors to explain the development of purchase intent. Further research may identify the impact of social media on repurchasing [73] and electronic word-of-mouth of green cosmetics. Moreover, the present study did not differentiate the effect of various social media platforms [66], content type and sources (peers, influencers, companies etc.) [61,74]. Instead, it handles social media as a homogenous place where consumers seek various information. The influence of the different social media sources and tools are welcomed to be integrated into the model.

Author Contributions: Conceptualization, R.-A.P. and Z.S.; methodology, R.-A.P. and Z.S.; software, R.-A.P.; validation, R.-A.P.; writing—original draft preparation, R.-A.P.; writing-review and editing, Z.S. and M.-A.A.; supervision M.-A.A.; project administration, R.-A.P.; funding acquisition, R.-A.P. All authors have read and agreed to the published version of the manuscript.

Funding: This research was funded by ELTE Márton Áron Szakkollégium Gazdaságtudományi Múhely.

Conflicts of Interest: The authors declare no conflict of interest. The funders had no role in the design of the study; in the collection, analyses, or interpretation of data; in the writing of the manuscript, or in the decision to publish the results.

\section{References}

1. Alwitt, L.F.; Pitts, R.E. Predicting Purchase Intentions for an Environmentally Sensitive Product. J. Consum. Psychol. 1996, 5, 49-64. [CrossRef]

2. Kong, W.; Harun, A.; Sulong, R.S.; Lily, J. The Influence of Consumers' Perception of green Products on Green Purchase Intention. Int. J. Asian Soc. Sci. 2014, 4, 924-939.

3. Dabija, D.-C.; Bejan, B.M.; Grant, D.B. The Impact of Consumer Green Behaviour on Green Loyalty among Retail Formats: A Romanian Case Study. Morav. Geogr. Rep. 2018, 26, 173-185. [CrossRef]

4. Dabija, D.C.; Bejan, B.; Dinu, V. How Sustainability Oriented is Generation Z in Retail? A Literature Review. Transform. Bus. Econ. 2019, 18, 140-155.

5. Statista. Available online: https://www.statista.com/topics/3318/natural-and-organic-cosmetics-in-europe/ (accessed on 19 April 2020).

6. Dangelico, R.M.; Vocalelli, D. "Green Marketing": An analysis of definitions, strategy steps, and tools through a systematic review of the literature. J. Clean. Prod. 2017, 165, 1263-1279. [CrossRef]

7. Statista. Available online: https://www.statista.com/study/38765/cosmetics-industry-worldwide-statistadossier/ (accessed on 24 July 2020).

8. Dimitrova, V.; Kaneva, M.; Gallucci, T. Customer knowledge management in the natural cosmetics industry. Ind. Manag. Data Syst. 2009, 109, 1155-1165. [CrossRef]

9. Statista. Available online: https://www.statista.com/statistics/803595/global-demand-for-natural-organicenvironmental-friendly-cosmetics/ (accessed on 24 July 2020).

10. McEachern, M.; McClean, P. Organic purchasing motivations and attitudes: Are they ethical? Int. J. Consum. Stud. 2002, 26, 85-92. [CrossRef] 
11. Liobikienè, G.; Bernatonienè, J. Why determinants of green purchase cannot be treated equally? The case of green cosmetics: Literature review. J. Clean. Prod. 2017, 162, 109-120. [CrossRef]

12. Chin, J.; Jiang, B.C.; Mufidah, I.; Persada, S.F.; Noer, B.A. The Investigation of Consumers' Behavior Intention in Using Green Skincare Products: A Pro-Environmental Behavior Model Approach. Sustainability 2018, 10, 3922. [CrossRef]

13. Murwaningtyas, F.; Harisudin, M.; Irianto, H. Effect of Celebrity Endorser Through Social Media on Organic Cosmetic Purchasing Intention Mediated with Attitude. KnE Soc. Sci. 2020, 152-165. [CrossRef]

14. Ma, G.; Rau, P.-L.P.; Guo, Z. The Effects of Environmental Awareness and Consumption Value on Green Makeup Product Purchase Intentions. Psychology 2018, 9, 1898-1916. [CrossRef]

15. Mangold, W.G.; Faulds, D.J. Social media: The new hybrid element of the promotion mix. Bus. Horiz. 2009, 52, 357-365. [CrossRef]

16. Lee, K. Opportunities for green marketing: Young consumers. Mark. Intell. Plan. 2008, 26, 573-586. [CrossRef]

17. Denegri-Knott, J. Consumers behaving badly: Deviation or innovation? Power struggles on the web. J. Consum. Behav. 2006, 5, 82-94. [CrossRef]

18. Singh, S.; Sonnenburg, S. Brand Performances in Social Media. J. Interact. Mark. 2012, 26, 189-197. [CrossRef]

19. Heinonen, K. Consumer activity in social media: Managerial approaches to consumers' social media behavior. J. Consum. Behav. 2011, 10, 356-364. [CrossRef]

20. Ajzen, I. The Theory of Planned Behavior. Organ. Behav. Hum. Decis. Process. 1991, 50, 179-211. [CrossRef]

21. Prakash, G.; Choudhary, S.; Kumar, A.; Garza-Reyes, J.A.; Khan, S.A.R.; Panda, T.K. Do altruistic and egoistic values influence consumers' attitudes and purchase intentions towards eco-friendly packaged products? An empirical investigation. J. Retail. Consum. Serv. 2019, 50, 163-169. [CrossRef]

22. Ghazali, E.M.; Soon, P.C.; Mutum, D.S.; Nguyen, B. Health and cosmetics: Investigating consumers' values for buying organic personal care products. J. Retail. Consum. Serv. 2017, 39, 154-163. [CrossRef]

23. King, T.; Dennis, C. Unethical consumers: Deshopping behaviour using the qualitative analysis of theory of planned behaviour and accompanied (de)shopping. Qual. Mark. Res. 2006, 9, 282-296. [CrossRef]

24. Ajzen, I. From intentions to actions: A theory of Planned Behavior. In Action Control; Kuhl, J., Beckmann, J., Eds.; Springer: Berlin, Germany, 1985; pp. 11-39.

25. Assarut, N.; Srisuphaolarn, P. Determinants of green product purchase intentions: The roles of environmental consciousness and product attributes. ChulalongKom. Bus. Rev. 2012, 32, 108-122.

26. Rehman, Z.U.; Dost, M.K. Conceptualizing Green Purchase Intention in Emerging Markets: An Empirical Analysis on Pakistan. In Proceedings of the 2013 WEI International Academic Conference Proceedings, Istanbul, Turkey, 16-19 June 2013.

27. Yazdanpanah, M.; Forouzani, M. Application of the Theory of Planned Behaviour to predict Iranian students' intention to purchase organic food. J. Clean. Prod. 2015, 107, 342-352. [CrossRef]

28. Tanner, C.; Kast, S.W. Promoting sustainable consumption: Determinants of green purchases by Swiss consumers. Psychol. Mark. 2003, 20, 883-902. [CrossRef]

29. Fleșeriu, C.; Cosma, S.A.; Bocăneț, V. Values and Planned Behaviour of the Romanian Organic Food Consumer. Sustainability 2020, 12, 1722. [CrossRef]

30. Oreg, S.; Katz-Gerro, T. Predicting proenvironmental behavior cross-nationally: Values, the theory of planned behavior, and value-belief-norm theory. Environ. Behav. 2006, 20, 462-483. [CrossRef]

31. Săplăcan, Z.; Márton, B. Determinants of Adopting a Zero Waste Consumer Lifestyle. Reg. Bus. Stud. 2019, 11, 25-39. [CrossRef]

32. Ahmad, S.N.B.; Omar, A. Generation Z: Can Personal Values Influence Their Intention To Purchase Natural Beauty Products ? Int. J. Innov. Soc. Sci. 2017, 2. Available online: https://kmc.unitar.my/index.php/ component/content/article/19-joomla/102-generation?Itemid=437 (accessed on 15 September 2020).

33. Kim, S.; Seock, Y.-K. Impacts of health and environmental consciousness on young female consumers' attitude towards and purchase of natural beauty products. Int. J. Consum. Stud. 2009, 33, 627-638. [CrossRef]

34. Kim, Y.J.; Njite, D.; Hancer, M. Anticipated emotion in consumers' intentions to select eco-friendly restaurants: Augmenting the theory of planned behavior. Int. J. Hosp. Manag. 2013, 34, 255-262. [CrossRef]

35. Bachleda, C.; Fakhar, A.; Hlimi, L. Sunscreen Purchase Intention amongst Young Moroccan Adults. Int. J. Acad. Res. Bus. Soc. Sci. 2012, 2, 132-150. 
36. Askadilla, W.L.; Krisjanti, M.N. Understanding Indonesian Green Consumer Behavior on Cosmetic Products: Theory of Planned Behavior Model. Pol. J. Manag. Stud. 2017, 15, 7-15. [CrossRef]

37. Hsu, C.-L.; Chang, C.-Y.; Yansritakul, C. Exploring purchase intention of green skincare products using the theory of planned behavior: Testing the moderating effects of country of origin and crossmark price sensitivity. J. Retail. Consum. Serv. 2017, 34, 145-152. [CrossRef]

38. Kim, H.Y.; Chung, J. Consumer purchase intention for organic personal care products. J. Consum. Mark. 2011, 28, 40-47. [CrossRef]

39. Mostafa, M.M. Antecedents of Egyptian Consumers' Green Purchase Intentions: A Hierarchical Multivariate. J. Int. Consum. Mark. 2006, 19, 97-126. [CrossRef]

40. Eze, U.C.; Ndubisi, N.O. Green Buyer Behavior: Evidence from Asia Consumers. J. Asian Afr. Stud. 2013, 48, 413-426. [CrossRef]

41. Mombeini, H.; Sha'abani, R.; Ghorbani, R. Survey the Effective Factor on Attitude \& Purchase Intention of Organic Skin and Hair Care Products. Int. J. Sci. Manag. Dev. 2015, 3, 819-826.

42. Douglas, M.; Isherwood, B.C. The World of Goods: Towards an Anthropology of Consumption; Psychology Press: London, UK, 1979.

43. Vermeir, I.; Verbeke, W. Sustainable Food Consumption: Exploring the Consumer "Attitude-Behavioral Intention" Gap. J. Agric. Environ. Ethics 2006, 19, 169-194. [CrossRef]

44. Gupta, S.; Ogden, D.T. To buy or not to buy? A social dilemma perspective on green buying. J. Consum. Mark. 2009, 26, 378-393. [CrossRef]

45. Tau, B.C.; Lau, T.C. Attitude towards the Environment and Green Products: Consumers' Perspective. Manag. Sci. Eng. 2010, 4, 27-39.

46. White, K.; Habib, R.; Hardisty, D.J. How to SHIFT Consumer Behaviors to be More Sustainable: A Literature Review and Guiding Framework. J. Mark. 2019, 83, 22-49. [CrossRef]

47. Ebreo, A.; Vining, J.; Cristancho, S. Responsibility for envoronmental problems and the consequences of waste reduction: A test of the norm-activation model. J. Environ. Syst. 2003, 29, 219-244. [CrossRef]

48. Oda, R.; Machii, W.; Takagi, S.; Kato, Y.; Takeda, M.; Kiyonari, T.; Fukukawa, Y.; Hiraishi, K. Personality and altruism in daily life. Pers. Individ. Differ. 2014, 56, 206-209. [CrossRef]

49. Smith, S.; Paladino, A. Eating clean and green? Investigating consumer motivations towards the purchase of organic food. Australas. Mark. J. 2010, 18, 93-104. [CrossRef]

50. Thøgersen, J. Green Shopping: For Selfish Reasons or the Common Good? Am. Behav. Sci. 2011, 55, 1052-1076. [CrossRef]

51. Zou, L.W.; Chan, R.Y. Why and when do consumers perform green behaviors? An examination of regulatory focus and ethical ideology. J. Bus. Res. 2019, 94, 113-127. [CrossRef]

52. Chryssochoidis, G.; Krystallis, A. Organic consumers' personal values research: Testing and validating the list of values (LOV) scale and implementing a value-based segmentation task. Food Qual. Prefer. 2005, 16, 585-599. [CrossRef]

53. Mostafa, M.M. A hierarchical analysis of the green consciousness of the Egyptian consumer. Psychol. Mark. 2007, 24, 445-473. [CrossRef]

54. Fauzi, N.F.; Hashim, R.A. Generation X and purchase intention toward green cosmetic and skin care products. Int. J. Bus. Manag. 2015, 1, 79-92.

55. Prakash, G.; Pathak, P. Intention to buy eco-friendly packaged products among young consumers of India: A study on developing nation. J. Clean. Prod. 2017, 141, 385-393. [CrossRef]

56. Kumar, A. Exploring young adults' e-waste recycling behaviour using an extended theory of planned behaviour model: A cross-cultural study. Resour. Conserv. Recycl. 2018, 141, 378-389. [CrossRef]

57. Yadav, R. Altruistic or egoistic: Which value promotes organic food consumption among young consumers? A study in the context of a developing nation. J. Retail. Consum. Serv. 2016, 33, 92-97. [CrossRef]

58. Schultz, P.W.; Gouveia, V.V.; Cameron, L.D.; Tankha, G.; Schmuck, P.; Franěk, M. Values and their Relationship to Environmental Concern and Conservation Behavior. J. Cross-Cult. Psychol. 2005, 36, 457-475. [CrossRef]

59. Magnusson, M.K.; Arvola, A.; Hursti, U.K.K.; Aberg, L.; Sjödén, P.-O. Choice of organic foods is related to perceived consequences for human health and to environmentally friendly behaviour. Appetite 2003, 40, 109-117. [CrossRef]

60. Li, Y.-M.; Lee, Y.-L.; Lien, N.-J. Online Social Advertising via Influential Endorsers. Int. J. Electron. Commer. 2012, 16, 119-154. [CrossRef] 
61. Wang, X.; Yu, C.; Wei, Y. Social Media Peer Communication and Impacts on Purchase Intentions: A Consumer Socialization Framework. J. Interact. Mark. 2012, 26, 198-208. [CrossRef]

62. Rauniar, R.; Rawski, G.; Yang, J.; Johnson, B. Technology acceptance model (TAM) and social media usage: An empirical study on Facebook. J. Enterp. Inf. Manag. 2014, 27, 6-30. [CrossRef]

63. Lin, C.A.; Kim, T. Predicting user response to sponsored advertising on social media via the technology acceptance model. Comput. Hum. Behav. 2016, 64, 710-718. [CrossRef]

64. Camilleri, M.A. The SMEs' technology acceptance of digital media for stakeholder engagement. J. Small Bus. Enterp. Dev. 2019, 26, 504-521. [CrossRef]

65. Kang, S.; Hur, W.-M. Investigating the Antecedents of Green Brand Equity: A Sustainable Development Perspective. Corp. Soc. Responsib. Environ. Manag. 2012, 19, 306-316. [CrossRef]

66. Bedard, S.; Tolmie, C.R. Millennials' green consumption behaviour: Exploring the role of social media. Corp. Soc. Responsib. Environ. Manag. 2018, 25, 1388-1396. [CrossRef]

67. Biswas, A. Impact of Social Media Usage Factors on Green consumption Behavior Based on Technology Acceptance Model. J. Adv. Manag. Sci. 2016, 4, 92-97. [CrossRef]

68. Oh, S. The characteristics and motivations of health answerers for sharing information, knowledge, and experiences in online environments. J. Am. Soc. Inf. Sci. Technol. 2012, 63, 543-557. [CrossRef]

69. Hsu, C.-L.; Lin, J.C.-C. Acceptance of blog usage: The roles of technology acceptance, social influence and knowledge sharing motivation. Inf. Manag. 2008, 45, 65-74. [CrossRef]

70. Bearden, W.O.; Rose, R.L. Attention to Social Comparison Information: An Individual Difference Factor Affecting Consumer Conformity. J. Consum. Res. 1990, 16, 461-471. [CrossRef]

71. Suki, N.M.; Suki, N.M. Consumption values and consumer environmental concern regarding green products. Int. J. Sustain. Dev. World Ecol. 2015, 22, 269-278. [CrossRef]

72. Holbert, R.L.; Kwak, N.; Shah, D.V. Environmental Concern, Patterns of Television Viewing, and Pro-Environmental Behaviors: Integrating Models of Media Consumption and Effects. J. Broadcast. Electron. Media 2003, 47, 177-196. [CrossRef]

73. Zahid, M.M.; Ali, B.; Ahmed, S.; Thurasamy, R.; Amin, N. Factors Affecting Purchase Intention and Social Media Publicity of Green Products: The Mediating Role of Concern for Consequences. Corp. Soc. Responsib. Environ. Manag. 2018, 25, 225-236. [CrossRef]

74. Chwialkowska, A. How Sustainability Influencers Drive Green Lifestyle Adoption on Social Media: The Process of Green Lifestyle Adoption Explained Through the Lenses of the Minority Influence Model. Manag. Sustain. Dev. 2019, 11, 33-42.

75. Min, C.; Lee, E.; Zhao, L. Mining Social Media Data to Discover Topics of Sustainability: The Case of Luxury Cosmetics Brands and Animal Testing. In Sustainability in Luxury Fashion Business; Lo, C.K.Y., Ha-Brookshire, J., Eds.; Springer: Singapore, 2018; Volume 6, pp. 93-111.

76. Zelezny, L.C.; Chua, P.-P.; Aldrich, C. Elaborating on Gender Differences in Environmentalism. J. Soc. Issues 2000, 56, 443-457. [CrossRef]

77. Pillai, S. Profiling Green Consumers based on their purchase behaviour. Int. J. Inf. Bus. Manag. 2012, 5, 15.

78. Pagliacci, M.; Manolică, A.; Roman, T.; Boldureanu, G. The consumers of green products. The case of Romanian Moldavia counties. Amfiteatru Econ. 2019, 21, 653-667.

79. Gunawan, D.D.; Huarng, K.-H. Viral effects of social network and media on consumers' purchase intention. J. Bus. Res. 2015, 68, 2237-2241. [CrossRef]

80. Goldsmith, R.E.; Lafferty, B.A.; Newell, S.J. The Impact of Corporate Credibility and Celebrity Credibility on Consumer Reaction to Advertisements and Brands. J. Advert. 2000, 29, 43-54. [CrossRef]

81. Sánchez-Fernandez, R.; Iniesta-Bonillo, M.A.; Holbrook, M.B. The Conceptualisation and Measurement of Consumer Value in Services. Int. J. Mark. Res. 2009, 51, 93-113. [CrossRef]

82. Roberts, J.A.; Bacon, D.R. Exploring the Subtle Relationships between Environmental Concern and Ecologically Conscious Consumer Behavior. J. Bus. Res. 1997, 40, 79-89. [CrossRef]

83. Izagirre-Olaizola, J.; Fernández-Sainz, A.; Vicente-Molina, M.A. Internal determinants of recycling behaviour by university students: A cross-country comparative analysis. Int. J. Consum. Stud. 2014, 39, 25-34. [CrossRef]

84. Tarkiainen, A.; Sundqvist, S. Subjective norms, attitudes and intentions of Finnish consumers in buying organic food. Br. Food J. 2005, 107, 808-822. [CrossRef] 
85. Sony, A.; Ferguson, D. Unlocking consumers' environmental value orientations and green lifestyle behaviors A key for developing green offerings in Thailand. Asia-Pac. J. Bus. Adm. 2017, 9, 37-53.

86. Matthes, J.; Wonneberger, A. The Skeptical Green Consumer Revisited: Testing the Relationship Between Green Consumerism and Skepticism Toward Advertising. J. Advert. 2014, 43, 115-127. [CrossRef]

87. Henseler, J.; Sarstedt, M. Goodness-of-fit indices for partial least squares path modeling. Comput. Stat. 2013, 28, 565-580. [CrossRef]

88. Hair, J.F.; Black, W.C.; Babin, B.J. Multivariate Data Analysis: A Global Perspective; Pearson Education International: London, UK, 2010.

89. Henseler, J.; Ringle, C.M.; Sinkovics, R.R. The use of partial least squares path modeling in international marketing. Adv. Int. Mark. 2009, 20, 277-319.

90. Chin, W.W. The partial least squares approach for structural equation modeling. In Methodology for Business and Management. Modern Methods for Business Research; Marcoulides, G.A., Ed.; Lawrence Erlbaum Associates Publishers: Mahwah, NY, USA, 1998; pp. 295-336.

91. Fornell, C.; Larcker, F.F. Evaluating structural equation models with unobservable variables and measurement error. J. Mark. Res. 1981, 18, 39-50. [CrossRef]

92. Hu, L.; Bentler, P.M. Cutoff criteria for fit indexes in covariance structure analysis: Conventional criteria versus new alternatives. Struct. Equ. Model. A Multidiscip. J. 1999, 6, 1-55. [CrossRef]

93. Henseler, J.; Hubona, G.; Ray, P.A. Using PLS path modeling in new technology research: Updated guidelines. Ind. Manag. Data Syst. 2016, 116, 2-20. [CrossRef]

94. Ali, F.; Rasoolimanesh, S.M.; Sarstedt, M.; Ringle, C.M.; Ryu, K.; Okumus, F. An assessment of the use of partial least squares structural equation modeling (PLS-SEM) in hospitality research. Int. J. Contemp. Hosp. Manag. 2018, 30, 514-538. [CrossRef]

95. Hair, J.F.; Sarstedt, M.; Ringle, C.M.; Mena, J.A. An assessment of the use of partial least squares structural equation modeling in marketing research. J. Acad. Mark. Sci. 2012, 40, 414-433. [CrossRef]

96. Teng, S.; Khong, K.W.; Ha, N.C. Palm oil and its environmental impacts: A big data analytics study. J. Clean. Prod. 2020, 122901. [CrossRef]

(C) 2020 by the authors. Licensee MDPI, Basel, Switzerland. This article is an open access article distributed under the terms and conditions of the Creative Commons Attribution (CC BY) license (http://creativecommons.org/licenses/by/4.0/). 